\title{
Small Blood Vessel Involvement in Diabetes Mellitus: Light Microscope Study of Specimens Obtained by Ear Lobe Biopsy
}

\author{
By \\ Axtonio Pieri, M.D., Paolo T. Scarpelit, M.D. and Michelangelo Rizzo, M.D. \\ Istituto di Patologia Medica Università di Firenze (Dir.: Prof. A. Luneder); Istituto di Urologia Università di Firenze
} (Dir.: Prof. A. Costantini)

Received July 2,1965

Summary. A light microscope study of small vessels of skin, obtained by ear lobe biopsy, was carried out on a group of diabetics (38), normal controls (15) and prediabetics (7). In the diabetic group two main histological lesions were found : 1 . perivascular cellular infiltration and 2. thickening of the basement membrane (adventitia reticularis). Arterioles, precapillaries, capillaries and venules are equally involved. The two main pathological features are present in the same subject but with a reverse ratio: the sections with most cellular proliferation show less thickening of wall and vice-versa. Neither thickening of basement membrane nor cellular infiltration was evident in normal controls and in prediabetics. The occasional thickening of the walls of small vessels, present in a small number of aged controls, cannot be considered typical since cellular perivascular infiltration was not found. Toluidine-blue staining has shown that perivascular infiltration consists mostly of mast cells. These cells are extremely polymorphic and various degrees of degranulation are constantly present. These lesions are found in $100 \%$ of our diabetics; they are more marked in the group of severe and long lasting diabetics and expecially when hypertension is associated. No relation of severity of vascular involvement to insulin therapy (dose, duration) was found.

Résumé. Une étude des petits vaisseaux de la peau du lobule de l'oreille prélevée par biopsie a été réalisée à l'aide du microscope à lumière, chez un groupe de sujets diabétiques (38), normaux servant de contrôles (15) et prédiabétiques (7). Dans le groupe des diabétiques on a constaté deux types principaux de lésions histologiques: 1. infiltration cellulaire périvasculaire 2 . épaississement de la membrane basale (《adventitia reticularis»). Les artérioles, les précapillaires, les capillaires et les veinules sont également atteints. Les deux principales manifostations pathologiques sont présentes chez le même sujet, mais avec un rapport inversé: les coupes présentant la plus forte prolifération cellulaire montrant un épaississement moindre de la paroi et vice-versa. Ni l'épaississement de la membrane basale ni l'infiltration cellulaire n'étaient évidents chez les sujets normaux ou chez les prédiabétiques. L'épaississement occasionnel de la paroi des petits vaisseaux, constaté chez un petit nombre de sujets témoins âgés, ne put pas être considéré comme typique étant donné que l'infiltration cellulaire périvasculaire n'a pas pu être trouvée. La coloration au bleu de toluidine a montré que l'infiltration périvasculaire consiste surtout en mastocytes. Ces cellules sont extrêmement polymorphes et des degrés variés de dégranulation sont constamment présents. Ces lésions ont été trouvées chez $100 \%$ de nos diabétiques; elles sont plus accentuées dans le groupe des diabètes graves et établis depuis longtemps, particulièrement lorsque l'hypertension se trouve associée. Aucune relation entre la gravité des complications vasculaires et l'insulinothérapie (dose, durée) n'a pu être trouvée.

Zusammenfassung. Bei einer Gruppe von 38 Diabetikern, 15 Normalpersonen und 7 Prädiabetikern wurden lichtmikroskopische Untersuchungen der kleinen Blutgefäße der bioptisch aus dem Ohrläppchen gewonnenen Haut vorgenommen. In der Gruppe der Diabetiker ließen sich zwei histologische Hauptveränderungen feststellen: 1. perivasuläre celluläre Infiltrationen und 2. Verdickung der Basalmembran (adventitia reticularis). Arteriolen, Präkapillaren, Kapillaren und kleine Venen sind gleichmäßig betroffen. Die beiden pathologisehen Veränderungen sind bei der gleichen Person vorhanden, doch in einem wechselnden Verhältnis: die Schnitte mit der stärksten Zellproliferation zeigen eine geringe Verdickung der Basalmembran und umgekehrt. Bei den Normalpersonen und den Prädiabetikern ließen sich weder eine Verdickung der Basalmembran noch eine zelluläre Infiltration feststellen. Die gelegentliche Wandverdickung kleiner Gefäße, die sich bei einer kleinen Anzahl älterer Kontrollpersonen fand, kann nicht als typisch angesehen werden, da sich keine zellulären perivasculären Infiltrate nachweisen lieBen. Die Toluidinblau-Färbung zeigt, daß die perivasculäre Infiltration meist durch Mastzellen bestritten wird. Diese Zellen sind stark polymorph, und verschiedene Grade der Degranulation sind immer vorhanden. Wir finden diese Veränderungen in $100 \%$ unserer Diabetiker. Bei der Gruppe des schweren und länger bestehenden Diabetes und vor allem bei gleichzeitig bestehender $\mathrm{Hy}$ pertonie sind sie stärker ausgeprägt. Eine Beziehung zwischen der Schwere der vaskulären Veränderungen und der Insulintherapie (Dosis, Verabreichungsdauer) konnte nicht nahgewiesen werden.
The interest in small blood vessel involvement in diabetes mellitus was confined for many years to the kidney and retina.

More recently, however, capillary changes similar to those found in the kidney and in the retina have been recognized in other organs including skin. These findings have suggested to many investigators that diabetes mellitus may be associated with diffuse capillary disease (diabetic microangiopathy) with the implication that diabetes may not be primarly a disease of the pancreas but instead represent a disorder of small vessels.

GOLDENBERG et al. ${ }^{16}$ described in a study on 92 amputated lower limbs from diabetics, lesions of small arteries and arterioles which appear to have a causal relation to diabetes. These lesions can be distin- 
guished from arterio-arteriolosclerosis by certain pathologic characteristic and by histochemical techniques: they are characterized by endothelial proliferation and deposition of a PAS-positive material in a reticulated pattern which is colloidal iron negative. These lesions were found in the adventitial tissues around vessels of the major arterial trunks, as well as in septal vessels of muscle, in the vascular supply to nerves and in the dermal vessels of the skin. AAGENAES and $\mathrm{MOE}^{1}$ found in a series of 24 diabetics changes in the capillaries of the skin in $\mathbf{1 6}$ cases. The capillaries of 9 nondiabetics were found normal except in one subject, 81 years old, in whom a slight thickening of the vascular walls was found. Pedersen and OLSEn 26 and more recently BANSON ${ }^{5}$ have confirmed, in a investigation of serial sections of skin-muscle biopsies, that diabetics suffer from characteristic diffuse lesions of small vessels, in particular a marked thickening of capillary basement membrane was almost constantly found.

Before going any further we should point out that the concept of basement membrane should be limited to that thin (electron dense) layer just below the endothelial cells which is only detectable by electron microseopy. What, by many investigators who have used light microscopy, is called basement membrane includes the adventitial tissue around the vessel and should more properly be called, according to VOLTERRA ${ }^{30}$ and AllarRa "adventitia reticularis".

Small blood vessel involvement in diabetes mellitus seems to occur in several areas and organs. Our knowledge concerning the extent of the diabetic microangiopathy is however still very incomplete. The present study deals with the small vessels of biopsy specimens from skin of the ear lobe of diabetic patients.

\section{Material and Methods}

The study includes three groups of individuals: nondiabetics, diabetics and prediabetics, matched by sex and age.

Nondiabetics were selected on the basis of normal glucose tolerance test in individuals with no history of diabetes in close relatives.

The diabetics were patients of the Institut of Medical Pathology, University of Florence (Dir.: Prof. A. LUNEDEI).

The prediabetics were chosen on the basis of normal glucose tolerance test and of a genetic predictability for the development of diabetes (history of diabetes in both parents).

Sixty subjects, 36 males and 24 females, with an average age of 51.5 years (range 13 to 82 years) have been studied to date. Of these 15 were nondiabetics, 38 diabetics and 7 prediabetics. In Table 1, diabetics are grouped and sex, age, diabetio heredity, duration of disease and insulin daily requirement, blood pressure and main vascular complications (retinopathy and/or nephropathy) are reported, with a semi-quantitative estimate of microvascular changes as seen by light microscopy. In Table 2, normal controls and prediabetics are grouped and sex, age, diabetic heredity (both parents), blood pressure and degree (semi-quantitative estimate) of microvascular changes are reported. In Table 3 the diabetics represented in this study are divided according to age (up to 50 and over 50 years), sex and the presence or absence of hypertension. Ten of the 38 diabetic patients ( $26 \%$ ) were in the age group up to 50 years; 24 were males $(63 \%)$ and 12 have hypertension $(31.5 \%)$.

Specimens of skin were obtained by ear lobe biopsy. Under local anesthesia $(0.5 \mathrm{ml}$ of $1 \%$ solution of procaine hydrochloride injected in the facial root of the ear lobe) biopsy samples were taken by a Keyses cutaneous punch No. 2. The material was fixed in Carnoy's fluid and formalin-mercuric chloride combination and embedded in paraffin. At beginning of this study we used both fixation methods; since preliminary findings have shown no significant difference in staining and histomorphology, during the later part of this research, one method or the other has been used.

Sections between six and eight microns thick were stained with hematoxylin and eosin (H. \& E.), with the PAS method, toluidine-blue and Unna-Pappenheim method.

\section{Results}

In our diabetic series two main histological lesions were found: 1 . perivascular cellular infiltration and 2. thickening of adventitia reticularis. Arterioles, precapillaries, capillaries and venules are equally involved; where lesions are more severe, capillaries showed greater tortuosity and a glomerulus-like appearance.

In the tuft the capillaries are usually involved but may be perfectly preserved in some sections. The two main pathological features are present in the same subject, and sometimes in the same slide, but with an inverse ratio: the sections with most cellular infiltration show less thickening and vice-versa. Therefore a semi-quantitative estimate of these two phenomena, taken separately, is not possible and in Table 1 , in the attempt to evaluate the degree (moderate + Marked ++ , very marked +++ ) of microvascular changes seen by light microscopy in several sections of each case, we were obliged to consider both changes together. Neither thickening of wall nor cellular infiltration was evident in the majority of normal controls. The occasional thickening of walls of small vessels, present in a small number of aged controls (two males No. 41 and No. 47 and 1 female No. 52), cannot be considered typical since cellular perivascular infiltration was not found.

The nature of cells forming the perivascular infiltration was not detectable by the current methods with H.E. and PAS staining. We have used UnnaPappenheim method and toluidine-blue in an attempt to clear this point. Unna-Pappenheim stained slices gave no contributory findings while toluidine-blue 
Table 1

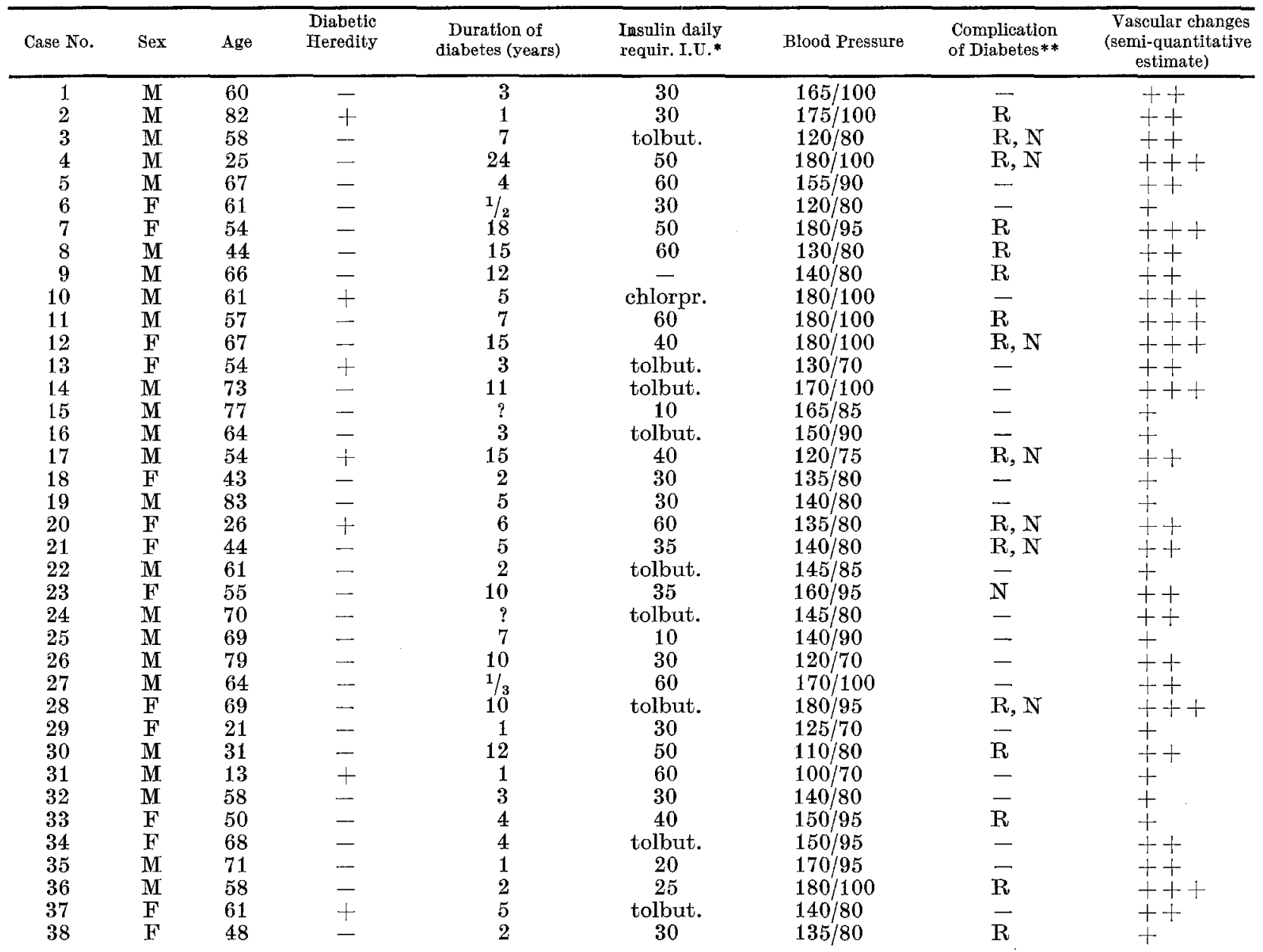

Table 2. Normal Controls

\begin{tabular}{cccccc}
\hline Case No. & Sex & Age & $\begin{array}{c}\text { Diabetic Here- } \\
\text { dity (both } \\
\text { parents) }\end{array}$ & Blood Pressure & $\begin{array}{c}\text { Vascular } \\
\text { changes (semi- } \\
\text { quantitative } \\
\text { estimate) }\end{array}$ \\
\hline 39 & M & 59 & - & $130 / 70$ & \\
40 & M & 69 & - & $165 / 85$ & \\
41 & M & 71 & - & $180 / 110$ & + \\
42 & M & 56 & - & $140 / 75$ & \\
43 & M & 61 & - & $150 / 90$ & \\
44 & M & 20 & - & $115 / 75$ & \\
45 & M & 13 & - & $115 / 70$ & + \\
46 & M & 50 & - & $130 / 80$ & + \\
47 & M & 81 & - & $175 / 100$ & + \\
48 & F & 20 & - & $120 / 70$ & + \\
49 & F & 45 & - & $130 / 75$ & + \\
50 & F & $\mathbf{5 6}$ & - & $125 / 80$ & + \\
51 & F & 60 & - & $135 / 90$ & + \\
52 & F & 66 & - & $185 / 110$ & + \\
53 & F & $\mathbf{7 0}$ & - & $155 / 95$ &
\end{tabular}

Pre-diabetics

$\begin{array}{ll}+ & 130 / 70 \\ + & 135 / 80 \\ + & 125 / 70 \\ + & 130 / 70 \\ + & 135 / 85 \\ + & 145 / 80 \\ + & 165 / 90\end{array}$

Table 3

\begin{tabular}{lcrrr}
\hline Type of patients & \multicolumn{2}{c}{ up to 50 yr. } & \multicolumn{2}{c}{ over 50 yr. } \\
& No. & $\%$ & No. & $\%$ \\
\hline Male hypertensive & 1 & 2.6 & 11 & 26.3 \\
Male normotensive & 3 & 7.9 & 9 & 23.9 \\
Female hypertensive & 1 & 2.6 & 5 & 13.2 \\
Female normotensive & 5 & 13.2 & 3 & 7.9
\end{tabular}

staining has shown that perivascular infiltration is mostly made by mast cells. These cells are extremely polymorphic and various degrees of degranulation are constantly present.

These lesions are found in $100 \%$ of our diabetics; they are more marked in the group of severe and long lasting diabetes and especially when hypertension is associated. No relation of severity of vascular involvement to insulin therapy (doses, duration) was evident. Endothelial cell proliferation is rarely found in our series. Finally no significant changes were found in our group of prediabetics.

* tolbut. = receiving tolbutamide orally chlorpr. = receiving chlorpropamide orally

$* * \mathrm{R}=\overline{\text { retinopathy } ; \mathrm{N}=\text { nephropathy. }}$. 


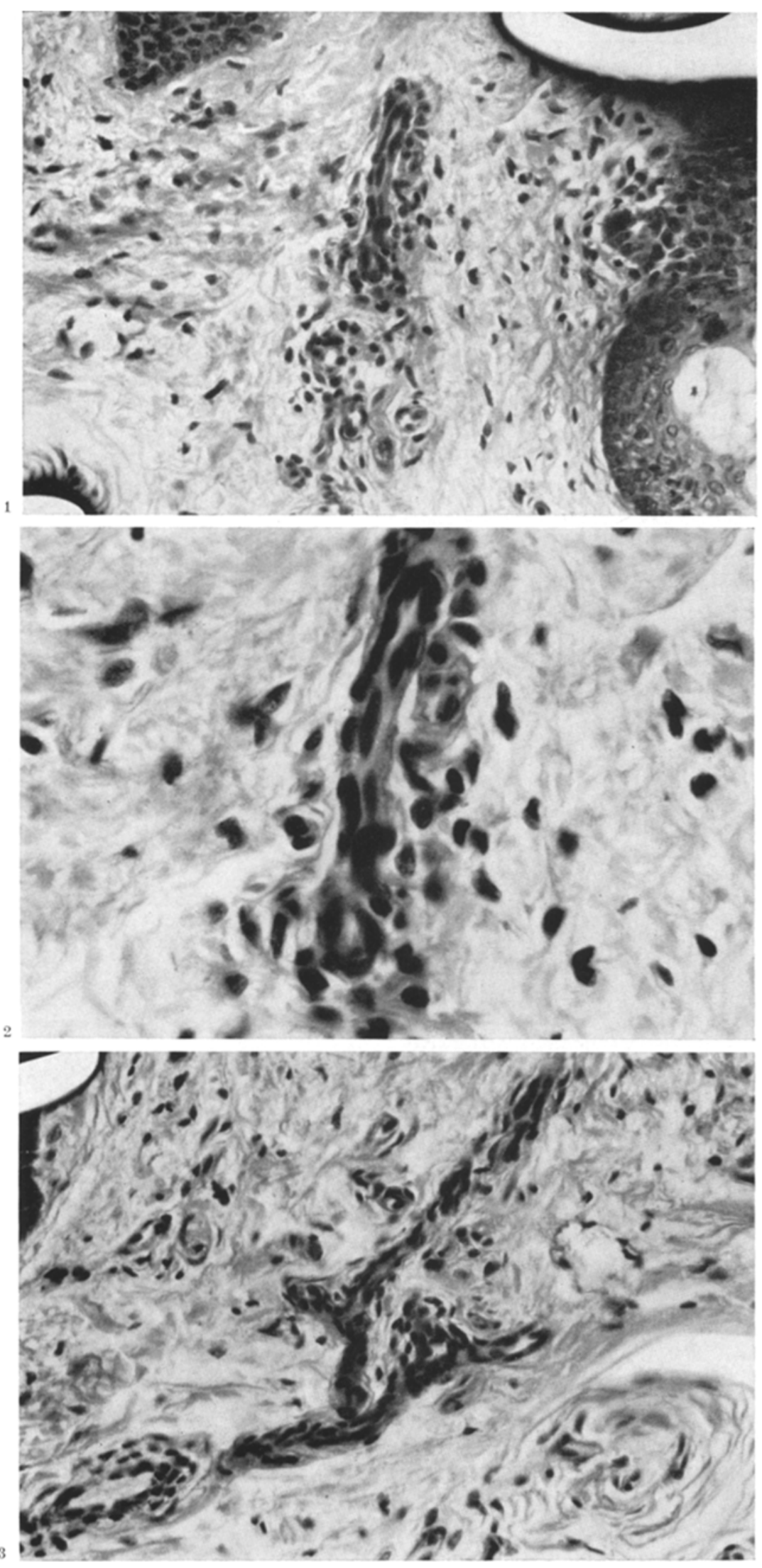

\section{Discussion}

The results of early physiological studies ${ }^{28,} 18,22,23,{ }^{6,27}$ showing, in diabeties,abnormalities in peripheral microcirculation, either spontaneous or under various vasoactive drugs, have stimulated further investigations on small vessel involvement in diabetes mellitus. These studies have led to the concept of a diabetic microangiopathy distinct from arteriosclerotic processes and with similar characteristics to those found in the retinal and renal glomerular vessels. Burstein, BLuMENTHAL and Soule ${ }^{11,12}$ collected histological evidence of the peculiarity of theselesions in the placentas of diabetic mothers; and GolDENBERg et al. in the lower extremity of patients with diabetic gangrene in the vasa nervorum of such extremities ${ }^{16}$, in the retina ${ }^{9}$ and in the intramural coronary artery branches $^{8}$. According to these authors the basic distinctive characteristics of this vascular disease are: endothelial proliferation (enlargement of cells may precede it) and deposition between endothelial cells of a network of small fibrils which are PAS positive and colloidal iron negative leading to a thickening of vascular walls. The same PAS positivity is shown also by elastic lamellae. Thickening of wall in light microscopy and widening of basement membrane in electron microscopy in small vessels of diabeties have been recognized by all subsequent investigators in various tissues and organs: in gastric mucosa ${ }^{4}$, inner ear $^{20}$, vasa

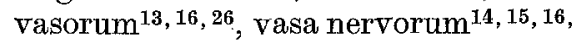
26, 29, synovial membrane ${ }^{2}$, muscle ${ }^{16}$, $19,1,26,31$ and $\operatorname{skin}^{16,1,26,17,10,5}$. In the majority of these studies endothelial proliferation, which was described by Blumenthal and Goldenberg and considered as one of the specific changes of small arteries and arterioles in diabetics is not mentioned. Neverthe-

Fig. 1. Low-power view of skin of diabetic patient (case No. 13) showing a marked perivascular cellular infiltration. PAS staining. Mag. $\times 350$

Fig. 2. High-power view of same blood vessel seen in fig. 1 from same case. Note hypercellularity and the thickness of the wall. PAS staining. Mag. $\times 840$.

Fig. 3. Low-power view of another section of same biopsy sample obtained from diabetic patient (case No. 13) showing thickened cutaneous blood vessels and less rich cellular infiltration. PAS staining. Mag. $\times 350$. 
less Pedersen and OLSEN ${ }^{26}$ report the occurrence of such a lesion in 5 out of 16 specimens of diabetics and occasionally in the control series too. HANDELSMAN et al. ${ }^{17}$ found endothelial proliferation in diabetics with nephropathy and retinopathy and more recently Moore and $\mathrm{F}^{2} \mathrm{RE}{ }^{24}$ reported characteristic changes in the blood vessels of the skin of the leg in 46 out of 52 diabetic cases. This angiopathy affected arterioles and capillaries principally and consisted of proliferation of the endothelium together with thickening of vascular wall. Hypercellularity is taken as evidence of endothelial proliferation but it could very well be the result of shrinking of the vessel's wall. At any rate in none of these studies are mitotic processes, which should be considered the main sign of cellular proliferation specifically reported.

In our series of diabetics we were able to confirm the thickening of can pillary, arteriolar and venular walls. This feature is often referred to as a result of widening of basement membrane. We feel, however, that this cannot be accertained by light microscopy since basement membrane is only detectable with the electron microscope. (The results of our electronmicroscopic study will be published later.) We suggest according to the concept of VOLTERRA ${ }^{30}$ and ALLARA ${ }^{3}$ the use of the term, adventitia reticularis.

Endothelial proliferative processes are negligible in our specimens and represent only an occasional nonspecific finding. We were much impressed, however, by the cellular perivascular infiltration which represents one of the most striking findings. Cellular infiltration is present in $100 \%$ of our diabetics and its amount seems to be in an inverse ratio to the thickening of the vessel wall; there are segments of the same vessel where thickening is

Fig. 4. High-power view of same blood vessel seen in fig. 3 from same case. Note the marked thickening of the vessels wall. PAS staining. Mag. $\times 840$

Fig. 5. High-power view of skin blood vessels with a glomerulus-like appearance (case No.4). PAS staining. Mag. $\times 840$.

Fig. 6. Microphotograph of a toluidine-blue stained section of skin of diabetic patient (case No. 12). Note the number of mast cells with various degree of degranulation around the vessel. Mag. $\times 840$
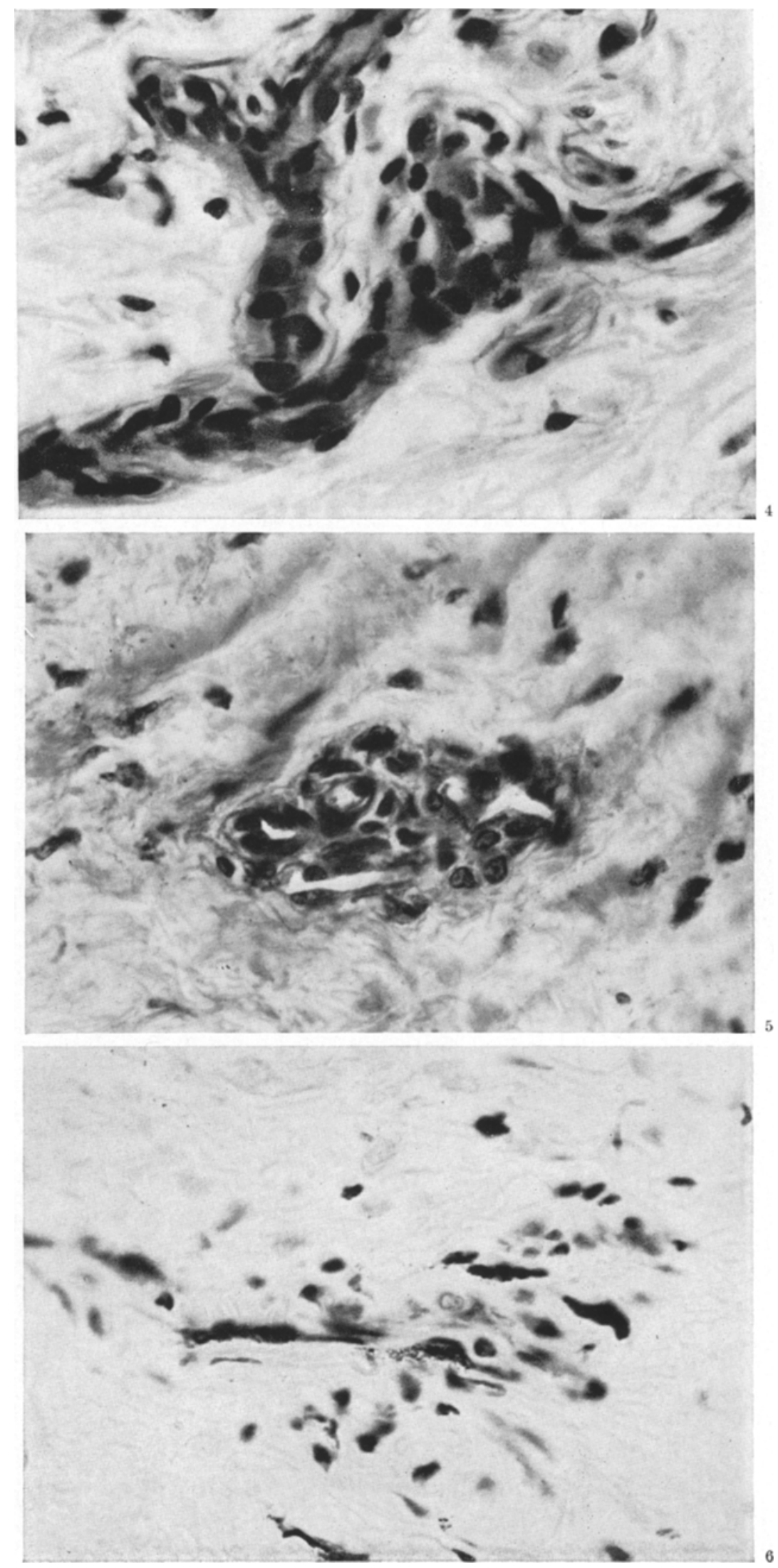
more marked and cellular infiltration less pronounced and vice-versa. By specific staining we are able to find that cellular infiltration is mostly made by mast cells. This finding, which to our knowledge has never been reported before, may likely be compared with the one reported by BANSON and $\mathrm{LACY}^{6}$. In addition to thickening of basement membrane of dermal capillaries, these authors have described in $88 \%$ of diabetics and in $23 \%$ of controls, a perivascular infiltration of cells enclosed by basement membrane, considered as pericytes. The cytoplasm of pericytes was indistinguishable from that of endothelial cells. It should be mentioned however that specific staining (Toluidine blue) for mast-cells was not used in this study. On the other hand, a significant increase in the number of mast-cells in the iris and ciliary body, as well as a metachromatically stained ground substance, is reported in human eyes with advanced diabetic retinopathy by LINNER and TENGRoTH ${ }^{21}$.

Since knowledge about the significance and function of mast cells is still incomplete any interpretation of our findings is uncertain, and they can only offer grounds for speculation. The fact that most mast cells in perivascular position undergo various degrees of degranulation might mean that they are in an active functional phase. Mast cells seem to participate in many physiological and pathological processes and particularly in the regulation of ground substance of connective tissue; they are also able to carry and perhaps to elaborate various active substances such as heparin, histamine and 5-hydroxytryptamine which are undoubtely active on vascular tissues and in blood coagulation. Their presence in a perivascular position may therefore be related to changes in capillary permeability or histological lesions. The presence of mast cells in an inverse ratio with thickening of the vessel wall could be better understood if the two pathological events could be chronologically identified.

Recently an immunogenic mechanism in the pathogenesis of diabetic microangiopathy has been suggested. $11,16,8,9,12$, The rôle of mast cells in experimental anaphylaxis $^{25}$ could be therefore suggestive in this respect.

\section{Acknowledgement}

Our deep gratitude goes to Prof. E. Alrara, Director of Institut of Human Hystology and Embriology, University of Florence, for reading our slides and for support, useful advice and constructive criticisms.

\section{Bibliographie}

1 Aagenats, O., and H. Mos: Light- and electron-microscopic study of skin capillaries of diabetes. Diabetes 10, $253-259$ (1961).

2 - and N.R. HAGENSEN: Tilfaelde of diabetisk artropati. Ugeskr. Laeg. 121, 572-577 (1959).

3 Aluara, E.: Il problema delle membrane basali. Arch. Ital. Anat. Embr. 55, 163-180 (1949).

- Sulla natura e sull'origine delle membrane basali. Mon. Zool. Ital., suppl. vol. 58, (1949).
- Modificazioni dello stato istiocitario e dello stroma nelle varie fasi funzionali di alcuni organi. Arch. Ital. Anat. Embr. 60, 321-377 (1955).

4 Angervall, L., G. Dotevall, and K. E. Lehmax: The gastric mucosa in diabetes mellitus: a functional and histopatological study. Acta Med. Scand. 169, $339-$ 349 (1961).

5 Banson, B. B.: Dermal microangiopathy in toes of human diabetics. Fed. Proc. 22, 2, 253, 557 (1963).

6 -, and P.E. LACY: Diabetic microangiopathy in human toes, with emphasis on the ultrastructural change in dermal capillaries. Am. J. Path. 45, 41-50 (1964).

7 BARANy, F.R.: Abnormal vascular reaction in diabetes mellitus: clinical physiological study. Acta Med. Scand. 152, suppl. 304 (1955).

${ }^{8}$ Blumenthal, H.T., M. Arex, and S. Goldenberg: A study of lesions of the intramural coronary artery branches in diabetes mellitus. Arch. Path. 70, 27-42 (1960).

9 - - - A non-atheromatous proliferative vascular lesion of the retina in diabetes mellitus. Role in the etiology of diabetic retinopathy. Amer. J. Med. 31, $382-396$ (1961).

10 BoJsen-MøLIER, F., P. GRøMBAEK, and J. RostgaARD: Light microscopic study of gastointestinal and skin capillaries in diabetes mellitus. Diabetes 12, 429-432 (1963).

11 Burstein, R., H.T. Bidumenthal, and S.D. Soule: Histogenesis of pathological processes in placentas of metabolic disease in pregnancy. II. The diabetic state. Amer. J. Obst. \& Gynec. 74, 96-104 (1957).

12 - - Vascular lesions of the placentas of possible im. munogenic origin in erythroblastosis fetalis. Amer. $\mathbf{J}$. Obst \& Gynec. 83, 1062-1068 (1962).

13 Dreyfus, P.M., S. Hakim, and R.D. Adams : Diabetic ophthalmoplegia. Arch. Neurol. \& Psychiat. 77, $337-349$ (1957).

14 FAgerberg, S.E.: Studies on the pathogenesis of diabetic neuropathy. II. Relation between clinically demonstrable neuropathy and pathoanatomic investigation of nerves. Acta Med. Scand. 156, 295-302 (1956).

15 - Diabetic neuropathy. Thesis. Acta Med. Scand. 164, suppl. 345 (1959).

16 Goldenberg, S., M. ALex, R.A. Joshr, and H.T. BluMENTHAL: Nonatheromatous peripheral vascular disease of the lower extremity in diabetes mellitus. Diabetes 8, 261-273 (1959).

17 Handelsman, M.B., T. G. Morrione, and B. Ghitman : Skin vascular alteration in diabetes mellitus. Arch. Intern. Med. 110, 108-115 (1962).

18 - , L.M. LigvirT, and H.Jr. Conrad : Small vessel dysfunction in patients with diabetes mellitus: 1-Skin temperature response to priscoline in the toes of diabetics. Amer. J. Med. Sei. 224, 34-38 (1952).

19 Hol.te, G.: Über Elektron Mikroskopische Befunde bei Diabetischer Angiopathie. Langenbecks Arch. Klin. Chir. 295, 253-258 (1960).

20 Jørgensen, M.B.: The inner ear in diabetes mellitus. Arch. Otolaryng. 74, 373-381 (1961).

${ }^{21}$ Linner, E., and B. Trigrath : Connective tissue changes in diabetic eyes. Acta Ophth. 40, 266-270 (1962).

22 Mendlowttz, M., E.B. Grossmann, and S. Alpert: Decreased hallucal circulation, an early manifestation of vascular disease in diabetes mellitus. Amer. J. Med. 15, 316-321 (1953).

${ }^{23}$ Megibow, R.S., S.I. Megibow, H. Pollak, J. J. BookMAN, and $K$. OsSERMAN: The mechanism of accellerated peripheral vascular sclerosis in diabetes mellitus. Amer. J. Med. 15, 322-329 (1953). 
24 Moore, J.M., and I. O. Frew: Peripheral vascular lesion in diabetes mellitus. Brit. Med. J. 2, 19-23 (1965).

${ }_{25}$ Mota, I.: The behavior of mast cells in anaphylaxis. Intern. Rev. Cytol. 15, 362-395 (1963).

- Mast cells and anaphylaxis. Ann. New York Acad. Sci. 103, 264-277 (1963)

26 Pedersen, J., and S. Olsen: Small-vessel disease of the lower extremity in diabetes mellitus. On the pathogenesis of the foot-lesions in diabetics. Acta Med. Scand. 171, 551-559 (1962).

27 Sigroth, K.: Reflex vasodilation of the fingers in the study of peripheral vascular disorders, with special reference to diabetes mellitus. Acta Med. Scand. 157, suppl. 325 (1957).

${ }^{28}$ StaRr, I. JR.: Studies on the circulation of the feet in diabetes mellitus with and without gangrene. Amer. J. Med. Sci. 180, 149-171 (1930).

29 Thomsen, A. A. Chr. : cit. by Pedersen and Olsen (26).

30 Volterra, M. : Einige neue Befunde über die Struktur der Kapillaren und ihre Beziehungen zur ,,sogenannten" Kontraktilität derselben. Zentr. f. inn. Med. 46, $876-881$ (1925).

- Sulla struttura dei capillari sanguigni e l'Anatomia del sistema reticolo-endoteliale. Mon. Zool. It. 36, $49-58$ (1925).

- Considerazioni sulla struttura dei capillari sanguigni e su una categoria di cellule a carattere emoistioblastico, in rapporto alla anatomia patologica ed alla fisiopatologia. La ,contrattilità " capillare. Lo Sperimentale 79, 618-642 (1925).

31 Zacks, S.I., J.J. Pegues, and F.A. Ellioti: Interstitial muscle capillaries in patients with diabetes mellitus: a light and electron microscope study. Metabolism 11, $381-393$ (1962).

\section{A. Pieri}

Istituto di Patologia Medica

Università di Firenze

Firenze / Italia 